\title{
Livestock mobility and animal health policy in southern Africa: the impact of veterinary cordon fences on pastoralists
}

Daniel J McGahey

Correspondence: daniel. mcgahey@gmail.com

African Wildlife Foundation, Conservation Centre, Ngong Road, Karen, P.O. Box 310, 00502, Nairobi, Kenya

\begin{abstract}
Greater understanding of how policies are restricting extensive pastoral production is needed, given the importance of livestock mobility to both social and environmental health in drylands. In southern Africa, communal pastoral rangelands continue to be enclosed and dissected by large-scale barrier fences designed to control livestock diseases and protect lucrative livestock export agreements. This paper looks at how these veterinary cordon fences are changing pastoral systems in Botswana, particularly patterns of resource access and livestock mobility. The results show how overall consensus of opinion towards fencing among pastoralists is positive; fences do restrict resource access yet on balance herding demands are reduced and livestock security improved. However, a minority of marginalised groups recognise that fencing restricts risk management strategies and increases competition for key resources, raising concern over more widespread social differentiation and increased vulnerability at the regional level. The paper demonstrates why a closer examination of the trade-offs and consequences associated with animal health policy options in Africa is needed, particularly to determine policy-marketing pathways that allow more flexible and opportunistic resource access within communal pastoral areas.
\end{abstract}

Keywords: Botswana, cordon fences, veterinary, livestock, pastoralism, mobility

\section{Background}

'Clearly, there will be occasions when movement restrictions to limit the spread of contagious diseases and the imposition of quarantine regulations are warranted. However, in the design of veterinary regulations and associated administrative arrangements, the trade-off between veterinary control and mobility must be taken into account' (Scoones 1995:17)

Livestock mobility is the principal means by which pastoralists cope with and take full advantage of natural resource variability in drylands (Scoones 1995, Behnke et al. 1993). Over the last two decades, scholars working with pastoral groups from both the northern and southern hemisphere have reported an almost universal decline in herd mobility, caused by a variety of factors ranging from the commoditisation of the pastoral economy to villagisation policies (cf. Fratkin 1997). Sedentarisation has been particularly influenced by declines in unfenced land available to pastoralists and their livestock after the widespread privatisation and enclosure of pastures for ranching,

(c) 2011 McGahey; licensee Springer. This is an Open Access article distributed under the terms of the Creative Commons Attribution License (http://creativecommons.org/licenses/by/2.0), which permits unrestricted use, distribution, and reproduction in any medium, provided the original work is properly cited. 
mechanised agriculture or conservation. Much of this change has been a consequence of the negative policy discourse surrounding pastoralism that often manifests in severely repressive rangeland policies designed to reform practices seen as irrational or environmentally destructive, whilst simultaneously improving economic productivity.

Formulating legislation that supports the spatial and temporal dynamism of natural resource use is now seen by many as one of the most important challenges for pastoral drylands (UNDP 2003, Niamir-Fuller 1999, Fratkin and Mearns 2003) ${ }^{\mathrm{a}}$. This follows the wider recognition of a 'new paradigm' for understanding dryland pastoral systems drawing heavily upon concepts of ecosystem instability or 'disequilibrium ecological theory' (Behnke et al. 1993). Advocates of this approach have shown how the policy implications are profound, requiring major changes in thinking at both the state and local level (Niamir-Fuller and Turner 1999, Scoones 1995). The future sustainability of pastoral drylands may well be dependent on the ability of decision makers to support herd mobility within almost all aspects of governance and service provision in drylands (Fratkin and Mearns 2003).

Recognition of the importance of herd mobility in determining environmental sustainability in non-equilibrium pastoral drylands has prompted researchers to understand drivers determining its contemporary use (Baker and Hoffman 2006,Coppolillo 2000,Adriansen and Nielsen 2002,Turner and Hiernaux 2002) and the ecological consequences of its decline (Reid et al. 2003,Boone and Hobbs 2003). Many of these studies have reported the growing importance of socio-economic rather than environmental factors in determining herding decisions at a microscale by influencing the availability of herding labour, quality of herd management and daily herd itineraries (cf. Baker and Hoffman 2006, Turner 1999). Most recent work has demonstrated how, even in industrialised countries, the use of livestock mobility remains an important strategy in response to environmental variability (McAllister 2010, Manzano and Casas 2010).

One of the main issues restricting livestock movement raised early in the 'new rangeland ecology' literature was the abundance of colonial-era policies founded upon conventional stability concepts. One specific area of policy, animal health, represents a conspicuous obstacle to pastoral mobility because the effective control of livestock diseases under most disease control legislation in Africa requires strict livestock movement restrictions. In discussing animal health regulations in relation to mobility Scoones (1995:16-17) noted for example:

'Most administrative arrangements (movement permits, veterinary regulations, etc.) assume a stable environment where movement is discouraged. However, under more dynamic ecological conditions, movement becomes increasingly central and such administrative structures impose a major cost on the production system.'

Until relatively recently, little specific research has sought to understand exactly what cost policies such as animal health legislation have on the pastoral production system and how these might be reduced. Notable exceptions include recent work on livestock marketing in eastern Africa that has begun to demonstrate the impediments colonialera animal health legislation designed for state-led marketing has on the growth of regional private sector-led trade, for example (McPeak and Little 2006). 
In southern Africa, sustained public sector investment in these disease control policies has facilitated the attainment of 'disease freedom' from certain areas, primarily through the construction of a network of large-scale veterinary cordon fences (Scoones et al. 2010). These facilitate the control of livestock movements upon extensive rangelands and allow the area-based disease freedom required to access lucrative beef export markets (Sutmoller 2002). By restricting mobility and dividing communal rangelands, veterinary cordon fences could have potentially detrimental impacts upon pastoralists and their flexible systems of resource access, yet apart from several brief time-bound assessments the exact societal costs of this approach remain poorly understood (see, e. g. Hobbs 1981,Hitchcock 1995,2002,Scott Wilson Resource Consultants 2000).

To address this knowledge gap, I investigated the impact of veterinary cordon fences upon livelihoods and natural resource access for pastoralists of Chukumuchu, a small settlement located in a heavily fenced area of Ngamiland district, northwest Botswana. The following section briefly describes the study area and situates it within Botswana's expanding network of veterinary cordon fences. Next, the paper provides a short review of the methods used in the research before comparing existing patterns of pastoral management, settlement and mobility with those recorded in the literature, primarily by anthropologists working in the 1970 s and 1980s. This shows that mobility has declined and the remaining sections describe and analyse how pastoral society and natural resource management has become progressively more sedentary for a variety of reasons. The influence of the region's veterinary cordon fences upon pastoral mobility and resource use is then extracted from this narrative of sedentarisation.

The described changes demonstrate how enclosure has increased societal vulnerability to the various risks associated with sedentary pastoralism in the Kalahari. Moreover, fencing has added to factors promoting the increasing commercialisation of the pastoral sector and disadvantaged younger herders by obstructing many of the traditional pathways into pastoralism. I argue that given these findings significant attention should be placed on current efforts to reform animal health policies in Africa, particularly at how the interests of natural resource-dependent pastoralists seeking flexible and opportunistic resource access arrangements can be reconciled against those of the commercial livestock lobby.

\section{Study Area}

\section{Veterinary cordon fencing in Botswana}

For the purposes of disease control, particularly foot-and-mouth disease which remains endemic in wild buffalo, Botswana is dissected by a network of veterinary cordon fences which divide the land into four: an export zone, buffer zone, vaccination/surveillance zone and a wildlife/foot-and-mouth disease (FMD) zone. Within these zones over $80 \%$ of livestock reared for the commercial sector are grazed on communal land (Darkoh and Mbaiwa 2002). The remaining cattle are reared on fenced tribal lands (tribal grazing lands policy, TGLP) or freehold farms, with the privatised land of the latter covering a meagre $6 \%$ of the country's total land area (Ndzinge et al. 1984). Elsewhere in southern Africa (Namibia, South Africa and formally Zimbabwe) a dualistic system exists whereby disease control, market infrastructure and support is focussed on the privatised ranching sector enclosed and protected from diseases endemic in communal areas by veterinary cordon fences (Scoones and Wolmer 2006). 
Because Botswana has successfully gained area-based disease freedom from communal areas and provided regional and export marketing opportunities to marginalised pastoralists many believe this approach can, and should, be replicated in areas of Africa where endemic diseases currently limit trade and export (cf. Kivaria 2003). Officials from livestock sections across sub-Saharan Africa are increasingly looking at Botswana as a disease management and marketing success story, including disease-free zone formation into ongoing rural development planning. Whilst there are signs that this approach may become increasingly less attractive for several economic and political reasons (see, e.g. Scoones and Wolmer 2006; Scoones et al. 2010), the nation's fences provide a unique opportunity to investigate what impact this policy might have upon the pastoral production system.

Within Botswana, Ngamiland district in the northwest of the country provides an excellent opportunity to evaluate the impact of fences constructed in living memory because it is often at the 'frontline' of government disease control efforts and a priority region in terms of disease control. The district is one of the most remote and inaccessible district in Botswana and its close proximity to areas where diseases such as cattle lung disease (or Contagious Bovine Pleuropneumonia, hereafter CBPP) and foot-andmouth disease (hereafter FMD) remain endemic in rural livestock and wildlife make the region a target area for investment in veterinary cordon fencing. Nine of the country's 18 documented disease outbreaks have occurred in the region (Hitchcock 2002), and, excluding fences put up over the last few years, the last five of the country's 17 major veterinary fences where constructed in the district (Figure 1).

Chukumuchu village Chukumuchu is a small settlement located within a sparsely populated area between the Okavango River and fenced international border with Namibia (Figure 2). The village itself is home to approximately 270 people, whilst a further 230 or more herders reside at cattleposts dispersed across the surrounding rangeland (Republic of Botswana 2001). The area remained largely unfenced until an

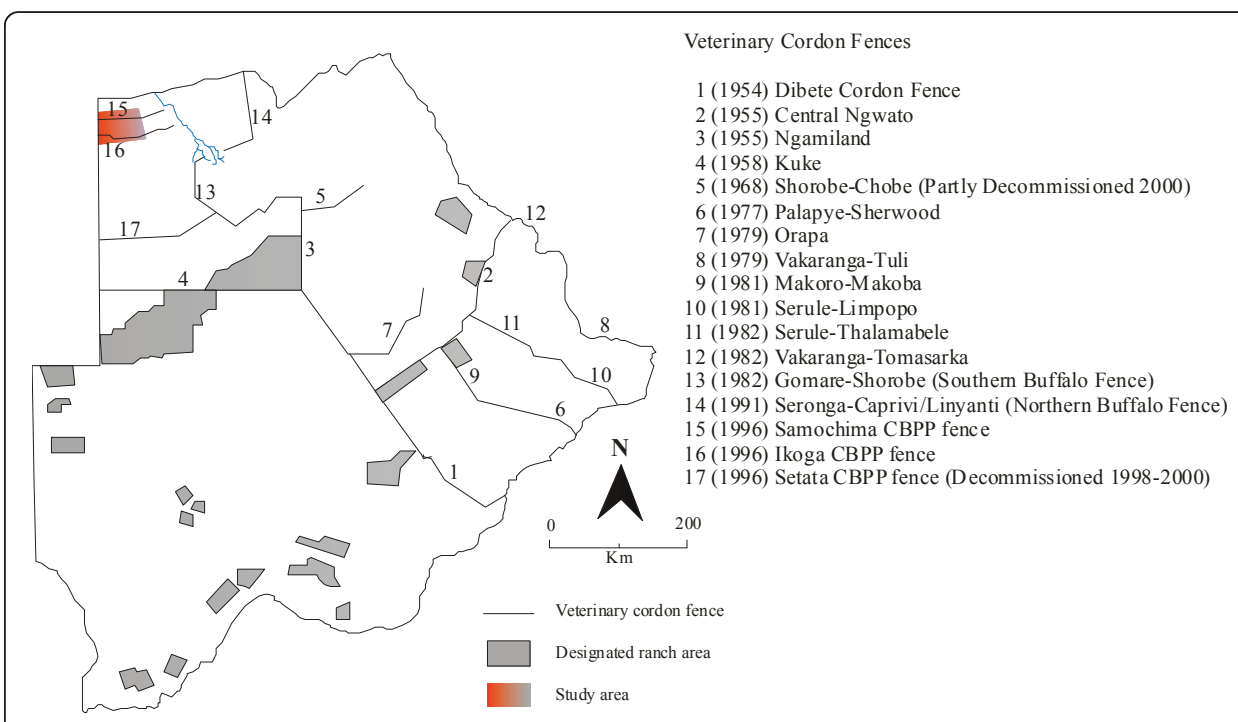

Figure 1 Botswana's veterinary cordon fences and fenced ranch blocks on 1954 to 1996 . The area marked in red represents the field site used in this project (Source: Adapted from Thomas and Shaw, 1991) 


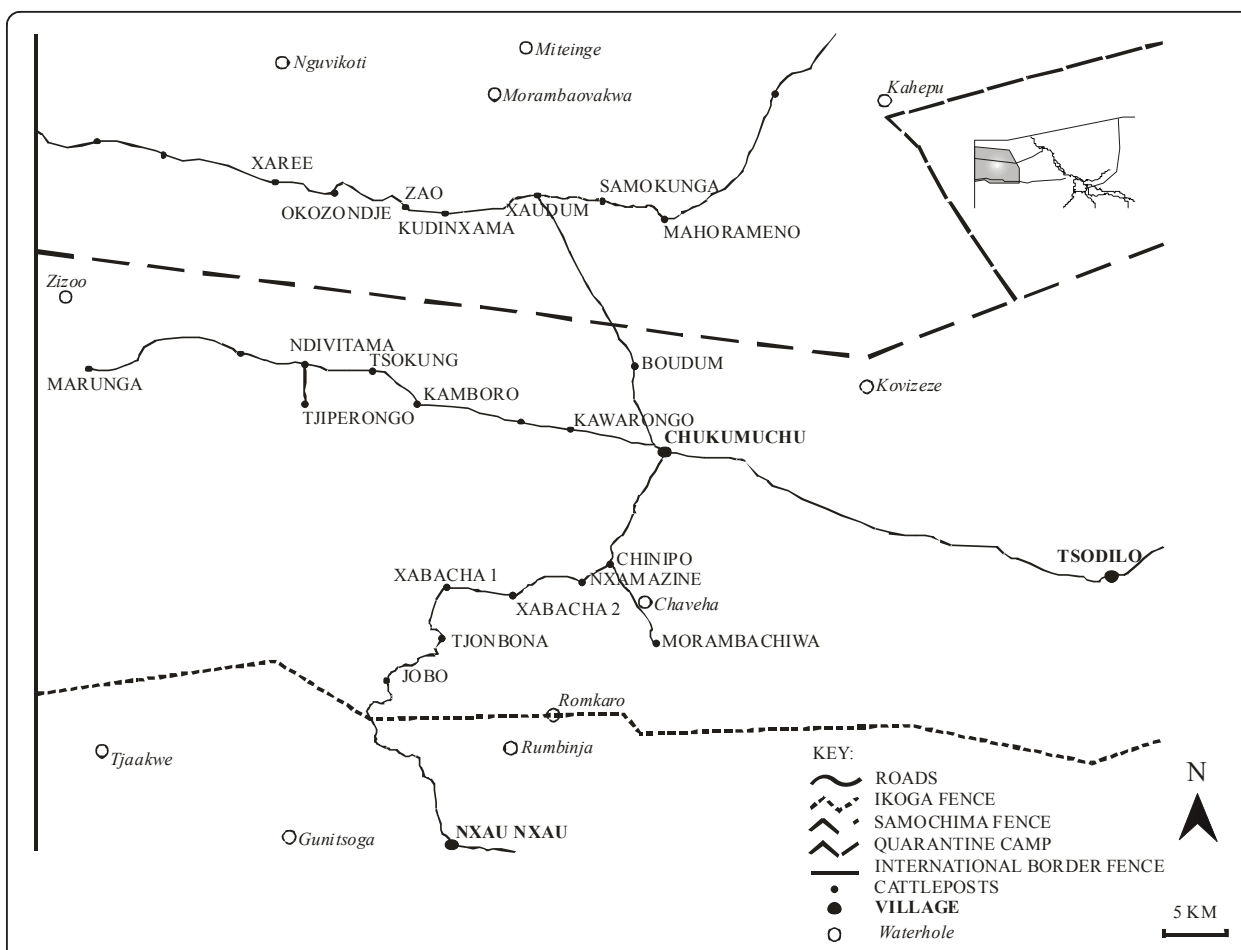

Figure 2 Chukumuchu village and surrounding waterholes and pans available to pastoralists in the past. Source: Fieldwork interviews (note: the location of all waterholes except Romkaro are approximate, based on map-supported interviews)

outbreak of CBPP in 1996 when several veterinary fences were rapidly erected in an effort to contain the disease. Two of these, the Ikoga and Samochima fences, now enclose the settlement to the north and south. Livestock movement is only permitted north through the fences via a few manned gates. To do so, herders must first apply for a permit, which can be obtained from the village when veterinary officials are present (usually during biannual vaccination campaigns) or from the district veterinary office at the nearest town; a return trip of over $100 \mathrm{~km}$. From a disease management perspective the area falls within the 'red zone' where cattle are vaccinated for FMD twice a year and cannot enter the export chain.

The climate is semi-arid with an average annual rainfall of between 400 and $500 \mathrm{~mm}$. Over the last 25 years, annual rainfall has been as low as $260 \mathrm{~mm}$ and as high as 780 $\mathrm{mm}$. The landscape is typical of the Kalahari with the undulating topography dominated by the presence of Kalahari-age vegetated longitudinal dunes orientated in an east-west direction, interrupted by several fossil river valleys, clay pans and depressions. The shrub and tree savannah varies from Burkea african, Pterocarpus angolensis and Baikiaea plurijuga communities typically found on sandy dune ridge soils to patches of interdune valley woodland dominated by Acacia spp. and Combretum imberbe.

The main ethnic groups are the pastoral Herero and the agropastoral Hambukushu. For the former group, Lake Ngami to the south represented the easternmost point of their territory until their numbers increased dramatically following the German-Herero war from 1904 to 1907 (Werner 2000). From the 1930s onwards, the group have spread northwards into the area, having rebuilt their herds (Pennington 1992). 
According to Herero and Hambukushu herders, they expanded pastoral production into the region from the 1950s, digging a series of dry season wells along low lying valleys.

\section{The research methods}

Pastoral systems are dynamic, necessitating a multitemporal approach to the analysis and understanding of change (Desta and Coppock 2004). Whilst some characteristics, strategies or cultures may remain relatively consistent, most communities are constantly adapting and changing to a variety of internal or external pressures. History, particularly historical struggles over access to, control of and exclusion from resources are vital in the quest to understand current resource use and management issues (Moore 1993). To investigate the impact of veterinary cordon fences, this study sought to understand how mobility was used in the past, how it is used now, along with the timing and cause of its demise. Only within this narrative of social change can the direct impact of veterinary cordon fence enclosure on pastoral livelihoods be illuminated.

Research focused on documenting social changes relating to resource access and mobility within pastoral society over the period leading up to, directly following, and the years since the area was enclosed by fences in 1996. It was considered particularly important to understand how such structures influence aspects of livestock management in a contemporary context, given both the internal dynamics described above and likelihood of future expansions to the fence network. The study was therefore intentionally situated in a region where fences have been constructed 'in living memory' so as to explore their impact upon contemporary livelihoods and natural resource use. Fieldwork was conducted from 2005 to 2006 and combined a variety of qualitative and quantitative methods within a multi-method approach (cf. Madsen and Adriansen 2004). Oral testimonies provided the main source of data, recorded during a series of focus group discussions, in-depth semi-structured interviews or informal discussions. Households and individuals interviewed at length were selected on the basis of a short community questionnaire survey $(n=53)$. This recorded data on basic socio-demographics, present livelihood activities, settlement history, and past and present livestock mobility. Further questions were also posed regarding local opinions of the fences, understandings regarding their purpose, along with local views regarding the work of the veterinary department. Emerging information concerning contemporary herd management and the use of natural resources in the past was complemented by direct observations during a period spent participating in day-to-day cattlepost management with key informants (i.e. herding, milking and watering livestock). Where the location of key resource areas could not be confirmed in the field due to logistical difficulties (i. e. remote inaccessible locations), the approximate position was estimated using natural resource mapping exercises aided by a printed Landsat TM satellite image (Theis and Grady 1991). This combined approach allowed the issue of natural resource enclosure to remain at the centre of analysis, whilst thoroughly investigating the local-level context of natural resource access and use. To protect the identity of herders on what has historically been a contentious issue, I use initials to refer to key informants throughout this paper. 
Pastoralism and mobility in northwest Botswana Existing literature on Herero mobility

Like most pastoral groups, Herero society is known to have changed dramatically over the past century. Prior to their forced migration to Botswana at the beginning of the twentieth century, the Herero were described by early missionaries as 'inveterate nomads' living a 'constantly nomadic life' moving from 'place to place with their herds, depending on the conditions of the pastures' (Werner 2000: 249). Anthropologists researching Herero in northern Botswana during the early 1980s compared their cooperative cattle management systems and transhumant land use practices to mobile pastoral groups from East Africa (Smith 1992). Other authors, however, suggest that Herero settlement patterns were more permanent than neighbouring Himba pastoralists and in comparison to the temporary camps and mobile arrangements of East African Turkana or West African Fulbe, the group's social organisation is much more tied to one place (Bollig and Gewald 2000).

Bollig and Gewald (2000) also note that the Herero use far less intensive herd management practices than East African pastoralists, usually herding livestock in the direction of intended pastures in the morning and relying on cattle returning at dusk for water. This form of 'herd-release' management is in fact the traditional cattlepost system employed throughout the Kalahari by Herero, BaKalagadi, Tswana and Mbukushu herders alike; to avoid working through the extreme heat of the day and generally based on the minimum expenditure of energy (Perkins et al. 2002). What differentiates the Herero from other Kalahari pastoral groups like the Tswana is their social organisation, which is clearly linked to their systems of opportunistic management and mobility. Central in this regard is their main homestead or onganda where several patrilineal-related households reside together. Each social group also own another homestead or temporary cattle camp at a waterhole where some of the men and their wives move with the cooperatively managed herd during the wet season (Almagor 1980).

The Herero could, therefore, be described as semi-sedentary pastoralists utilising opportunistic management and mobility in order to cope with, and take advantage of the highly variable resource base (Almagor 1980). Whilst the Herero may have been more mobile in the past, the main onganda has remained sedentary since at least the late 1970s in Botswana (Vivelo 1977) and for over 58 years in Namibia (Bollig and Gewald 2000). However, the Herero may still use mobility as a principal drought-coping strategy and herd management technique. Since the late 1970s in Namibia, Herero pastoralists have been known to truck or trek cattle from one grazing reserve to another during prolonged droughts (ibid: 28). In Botswana, the Herero objected virulently to enclosure by the proposed tribal grazing lands policy (TGLP) ranches near Lake Ngami, largely on the grounds of the reduced mobility this would bring (Almagor 1980).

\section{Present-day livestock management surrounding Chukumuchu}

Though the Herero may have retained some form of pastoral mobility, there are further social and economic changes that have occurred within Herero society since their (re)pastoralization and expansion in northwestern Botswana. Today, livestock production in the region is centred on a series of permanent hand-dug wells situated along interdune valleys. At almost every cattlepost, at least one owner possesses a 
2000-l plastic water tank, petrol or diesel generator and electric water pump. All of this equipment can be purchased at hardware stores in the nearby town. For those who lack the resources to purchase this equipment, water can be accessed either for free at a government borehole near the village; through formal payment to a principal well owner; through informal herding arrangements where access forms part of payment in kind; and finally at private wells operated by hand, using buckets lowered and raised on a winch system (for those fortunate enough to be gain a permit from the land board and wealthy enough to afford the construction costs).

A second significant change from the pastoral system described during the 1980s is the region's social organisation. With the mechanisation of most water sources very little labour is now required at the cattleposts. Most households have their main homestead in the village where children attend school and family members often gain informal income from a variety of sources (e.g. brickmaking, thatching, dress making, labour-intensive public works programmes, beer sales). Typically, one or two males remain at the cattlepost to milk, water and kraal the livestock daily. A few wealthy farmers own a four-wheel-drive vehicle which is principally used to collect fuel from the nearest town to run the water pumps. Several cattleposts were managed by contract herdsmen for absentee owners living in the nearby town of Shakawe. At one cattlepost, a single herder was found to be managing several herds for different absentee owners.

\section{Pastoral mobility and social organisation 1950-1980}

Because the present nature of pastoral mobility and social organisation in northwestern Botswana clearly diverged from that documented by anthropologists in the 1970s and 1980s, significant research effort was directed towards documenting changes to pastoral mobility and management from the period pastoralists moved into the region, to the present day. According to (Pennington 1992), Herero pastoralists have been expanding their territory to the north of Lake Ngami since the 1930s predominantly along the western margins of the Okavango Delta. Their numbers remained low in the dry Kalahari sandveld to the west of the Delta fringe, however, until the 1950s after which Herero settlement increased (Lee 1984).

Oral testimonies from several elderly herd patriarchs interviewed in the Chukumuchu area confirmed that Herero and Mbukushu households moved into the region from the 1950s onwards. Most cited stock losses to predators along the Okavango River and shortages of grazing are reasons for their migration inland and they clearly described how they expanded first along the Xaudum valley where water could be easily accessed from shallow pit wells. By the 1960s, there were wells throughout the valley and cattleposts had begun to be established at large waterholes in the interdune valleys between Xaudum and Nxau Nxau. One of these was established at Chukumuchu, a large waterhole retaining water long after the wet season. Chukumuchu remained a large Herero cattlepost until in 1991 when a government settlement was formed at the site.

Discussions about past herd mobility and management revealed that herders could be divided into three groups according to the type of seasonal livestock movement practised from when the area was first occupied by pastoralists in the 1950s to the early 1980s. First, some people with small herds of cattle, mostly of Mbukushu origin, 
have never practised seasonal mobility and preferred to fence fields against livestock damage and practise 'herd-release' or 'free-range' management. Second, pastoralists engaged in arable agriculture with larger herds practised regular seasonal moves to a particular waterhole during the growing season partly to relieve pressure on grazing and water, and partly to avoid crop damage. Finally, pastoralists with large herds, primarily of Herero origin, would make seasonal camps at waterholes located within a certain pasture area, sometimes utilising more than one waterhole per wet season and sometimes visiting different pasture areas in different years.

There are, therefore, two groups of pastoralists who conducted seasonal herd movements in the past. For those with arable fields, mobility was primarily conducted to protect arable lands from livestock damage and reduce the need to rigorously maintain labour-intensive thorn fencing. 'We moved the cattle to our camp at Chaveha just after the rains to stop the cattle destroying the crops (November 2005)', said MT an elderly Hambukushu man from Chukumuchu. According to MT, he would herd the cattle with his sons and make a temporary camp at the waterhole each year, remaining until the water dried up, sometimes as late as June or July. Meanwhile, the women and remaining children would look after the fields (bird scaring, harvesting, threshing) and attend to small stock. A similar pattern was practised by KM, a Mbukushu man from the cattlepost Xabacha II. KM used to camp at the Romkaro waterhole, now dissected by the Ikoga fence, which he says held water for up to 3 months after the rains had stopped. ${ }^{\mathrm{b}}$

The second form of seasonal mobility practised in the past was that of large herdowning Herero pastoralists. For Herero herd patriarchs, the primary motivation was to alleviate the resource pressure on grazing surrounding permanent cattleposts. Another reason to move was the ease of watering livestock at waterholes as this requires far less labour than permanent hand-operated water sources. In an annual cycle, Herero herd patriarchs would trek cattle to temporary camps near one or more large waterhole, from which livestock would be managed using the usual 'herd-release' method. Pastoralists would generally move with their livestock after the first major rainfall event of the wet season (usually between October and December), remaining until the water sources dried out (usually May or June). Typically, male household members or contract herders would move to cattle camps, whilst wives and extended family would remain behind at the main cattlepost to look after smallstock and a small milking herd. Some Herero women would visit the camps to make butter and oil from milk, as they report that yields were good during the wet season. Most households would therefore utilise waterholes no further than a day's walk of the main dry season homestead. These arrangements are similar to those noted by (Almagor 1981) for Lake Ngami Herero.

Although herders could provide the name and approximate location of at least four or five waterholes regularly used within $5-10 \mathrm{~km}$ of their dry season cattlepost, most would spend the entire wet season camped at a single waterhole. For example, KK, a Herero herd patriarch and owner of Jobo cattlepost, described moving his herd over different years to Ramkaro, Rumbinja, Gunisoga and Tjaakwee waterholes (Figure 2). All of these are now partly or fully enclosed by the Ikoga fence. Herders such as KK would vary the waterhole visited mainly on the basis of where the rains were heaviest. ${ }^{c}$ 
This is a similar pattern of mobility to the 'meeting the rain' management described by Adriansen and Nielsen (2002) for Fulani pastoralists in West Africa.

Although the precise years when mobility declined were difficult to establish, most herders cited the early 1980 s as the time when they became fully sedentary. For pastoralists with large herds, the transition to sedentary management often involved constructing a second permanent well at their favoured wet season waterhole. This allowed greater flexibility enabling the owner to split the family herd, use mobility in emergencies or continue to make regular seasonal moves to one specific area. This restructuring of pastoralism is considered in relation to the fences in more detail below.

Once the nature of past mobility was established, the questioning centred on the main factors driving sedentarisation. These enquiries revealed several main forces causing sedentarisation. First, an out-migration of households and farm labour to regional towns and large villages caused by regional socio-economic developments. Second, a gradual erosion of the traditional Herero household structure and cooperative herd management system. And finally, a period of Herero repatriation to Namibia from 1993 to 1996, in an attempt by some to regain Herero political autonomy. All of these changes caused a reduction in the availability of labour at the region's cattleposts and ultimately reduced herd mobility. In the following sections, each of these forces are briefly described in turn, before examining the situation regarding pastoral mobility and opportunistic management which existed at the time of the CBPP outbreak, and the subsequent impact of the fences on pastoral management.

\section{Pastoral sedentarisation pre-1996}

\section{Out-migration and settlement in villages or towns c. 1970s-1980s}

One of the main factors causing pastoral mobility to decline during the 1970s and 1980s was labour shortages at the cattleposts. In response to the question, 'Why do you no longer move your cattle seasonally?' one Herero herder replied simply, 'I can't take the cattle away to waterholes as I don't have enough herd boys to help and my wife is usually in the village so there would be no one to look after the smallstock' (November 2005). The reduction in labour availability has been driven by an ongoing process involving the settlement of household members in nearby villages or towns. This followed improvements in the quality of public services and various physical capital assets in the region, as roads and villages have developed through government investment in rural development. The expansion was accompanied by improved social welfare and livelihood opportunities in larger villages through increases in waged labour, education, health care and trade. In Ngamiland district as a whole, these trends can be seen in the disproportionate increase in the population of the district's main town Maun, whose population has increased more than three times the rate of the district as a whole (Bensen and Meyer 2002). In the Chukumuchu region, household members started to reside in large villages such as Shakawe and Nxamasere from the late 1970s to 1991 when the village of Chukumuchu was established by the Botswana government. Since this time Chukumuchu has steadily expanded with the construction of a school and clinic which attracted further out-migrations of rural households and resulted in the bilateral social organisation observed in the study area today. 
For Herero pastoralists, the socio-economic changes documented above represented an erosion of their social organisation, which had major implications for herd management and mobility. According to local herd patriarchs, elements of the patrilineal homestead or onganda remained intact in the region until the early 1980s, which is in agreement with anthropological research of the time (see, e.g. Almagor 1981). However, the Herero household structure had already started to become increasingly compromised as more generations of the Herero sought outside employment and education. As a result, many Herero families began to establish their main homesteads in regional towns and large villages and started to manage their cattle from a distance, leaving mainly older males and unemployed young men at the cattlepost. KE, a Herero well owner from the Xaudum valley, described the changes that occurred within Herero society:

'During the 1970s many of the Herero family members became educated and found work in the towns. By the late 1970s most of the mothers and children had left the cattleposts and moved to Shakawe or Nxamasere and in the early 1980s many families stopped making seasonal movements to waterholes (November 2005)'.

Most households stopped going on seasonal livestock movements due to the lack of extended family members able to remain at the main cattlepost and tend to calves and smallstock. Whilst cattle can often be left to roam freely in an area they know, small ruminants require daily herding because they can easily get lost, stolen or taken by predators (Adriansen and Nielsen 2002). In most pastoral societies, cattle are usually the responsibility of the household head, whilst small ruminant herding is the responsibility of children or women. The change in Herero household structure caused many to reduce the number of smallstock kept at the cattlepost as they could no longer be looked after by children and female members of the household. Once again, this trend is supported by anthropological observations amongst Ngamiland Herero in the late 1970s (Almagor 1981). During the $1970 \mathrm{~s}$ and $80 \mathrm{~s}$, therefore, pastoralism for the Herero in the Chukumuchu rangelands was characterised by declines in labour availability and reduced pastoral mobility. However, a further decline in the number of pastoralists likely to practise seasonal mobility occurred after Namibian independence in 1990.

\section{Herero repatriation 1990-1996}

The Herero of Botswana have often been described as a proudly independent ethnic group with aspirations to return to their homeland in Namibia (Pennington and Harpending 1991, Almagor 1981). These aspirations came into fruition following Namibian independence when the governments of Botswana and Namibia agreed on an organised repatriation of Herero pastoralists to Gam in Namibia (Kruger 1998). Whilst official data regarding the scale of the Herero repatriation from the Chukumuchu region are lacking, the decline in Herero households was evident from the number of newly established Hambukushu and Bayei herders in the region and several abandoned and vacant Herero wells.

Almagor (1981: 49) noted that the Herero were closely monitoring political developments in Namibia as early as the late 1970s and were reluctant to invest in borehole technology or deepen their economic involvement at the time as a result of 
'encouraging signs of an approaching independence.' Today, most Herero engaged in livestock production in the study area have invested in water pumping technology or village-based homes and many have become more involved in the local village institutions and regional politics. SM, a Herero man in his fifties, for example, is the local councillor for the region and a prominent figure in the community. According to SM before the cull he owned over 100 cows and used to practise seasonal mobility. After the cull, he decided to keep fewer cattle and invest in water pumping and storage equipment,

'A large herd need a lot of water, its hard work watering by hand, so you must move to search for waterholes in the wet season. I wanted to stop having to move around so much so I invested my compensation in a water tank and pump, you can't move these things easily (October 2005).'

It would appear, therefore, that the Herero repatriation resulted in the loss of households less integrated into regional society, less likely to have invested in borehole technology or sedentary infrastructure, and more likely to use mobility. For these households, mobility was an important part of management as they preferred to 'continue to rely on the natural resources' and not invest in 'expense and activity which would deepen their economic involvement in a country which they see as their temporary host' (ibid: 49).

Social changes in the region from the early 1980s to the early 1990s therefore caused some fundamental alterations to pastoral management and herd mobility. Pastoralists faced with an out-migration of household members to large villages and labour shortages were forced to decrease their herd mobility. The Herero repatriation may have also resulted in the loss of many of the most mobile pastoralists. Although some herders may have begun to adapt to these changes before the outbreak of CBPP in 1995, the CBPP cull caused an enormous disruption to the pastoral economy which resulted in a major restructuring of pastoralism in the Chukumuchu region.

The CBPP outbreak 1995-1996

In February 1995 Botswana's first CBPP outbreak for nearly 60 years occurred in the Xaudum valley to the north of Chukumuchu. The outbreak started after infected livestock entered Botswana from Namibia, probably as a result of the post-independence relaxation of military border patrols and the ongoing process of Herero repatriation. State veterinarians moved quickly to contain the disease, using emergency powers to construct three new veterinary cordon fences. These failed to hold the outbreak and in April 1996 the Department of Animal Health and Production decided to 'stamp out' the infection by ordering the cull of Ngamiland's 320,000 heads of cattle.

The depopulation of livestock in the Chukumuchu region, and throughout Ngamiland, caused the migration of many households and the majority of rural farm labourers to village service centres or regional towns. This migration, and the provision of compensation and relief work which followed, forced the rapid acceleration and consolidation of many longer-term tensions which had hitherto been driving changes within the pastoral management systems of the Chukumuchu region. Firstly, many households took the opportunity to establish a second homestead in the village, especially as there were widespread rumours that the Chukumuchu veterinary zone would 
be restocked first. For example, 12 out of 24 households questioned in the village migrated to Chukumuchu and established homesteads in 1995 and 1996. Many of these households migrated from the infected red zone to the north of the Samochima fence, with seven of these 12 migrating from the Xaudum valley.

The CBPP cull and subsequent migration of households to large villages caused enlightenment among young herdsmen who quickly realised the benefits that commoditisation had brought to service centres and soon became entrenched in village life. According to one young man,

'After the cull there were so many young people just sitting around in big groups enjoying themselves. The herd boys realised what they were missing and many decided then not to go back (October 2005)'.

The CBPP cull, therefore, prompted a further out-migration of potential herders who soon became engaged in alternative income opportunities within large villages and towns. The decline in pastoral labour has been widespread in Ngamiland. This can be seen in the official statistics for formal employment in the region. In 1991 the agricultural sector was the largest employer with $40 \%$ of the district's labour force, whereas only 14\% were employed in 2001 (Bensen and Meyer 2002). The majority of households became reliant on emergency food rations and labour-intensive public works programmes for income (ibid, p.17).

For pastoralists, the CBPP cull and subsequent compensation payments provided a huge increase in the availability of cash for the household economy. After the cull, the government offered several compensation options, from all cash compensation (compulsory for small farmers with up to ten heads of cattle) to 70\% cash and 30\% restocking, or 30\% cash and 70\% restocking. Regionally, most farmers opted to receive high rates of cash compensation (Fidzani et al. 1999). ${ }^{\mathrm{d}}$ In the Chukumuchu region $43.4 \%$ of households surveyed opted for $100 \%$ cash compensation and the remaining households opted for compensation involving either $30 \%$ or $70 \%$ restocking and the rest cash. ${ }^{\mathrm{e}}$ Most households spent the money on immediate or routine household expenditure, especially households with small herds of cattle. However, several households choose to invest their money on major purchases such as vehicles and water pumping technology. These purchases were a direct adaptation to the pressures forcing sedentarisation (i.e. labour shortages) and represented the beginning of a period of agricultural restructuring in the Chukumuchu rangelands.

Ngamiland's pastoral lands were restocked between April 1997 and March 1998 with 70,000 cattle (Mullins et al. 2000). As discussed earlier, once they received their livestock, pastoralists in the Chukumuchu veterinary zone could only move livestock up through the zones with the requisite permits from the Department of Animal Health and Production (DAHP). As a result, many abandoned shallow wells previously used in the Xaudum valley to the north, in favour of wells located along the interdune and dry river valleys of the Chukumuchu region. A period of pastoral restructuring ensued as households reorganised their livestock management arrangements within the new veterinary disease control zone. Pastoralists with the financial resources to employ a contract herder now had to entice labour away from increasing employment opportunities available near villages and urban centres. Whilst households with cattleposts 
within close proximity to the village could rely on young family members to provide herding labour after school and at weekends, owners of remote cattleposts struggle to find contract herders willing to work in the rangelands. Several herd patriarchs spoke of matching the minimum labour-intensive public works wage and providing extra incentives such as food and other daily consumables, in order to attract labour. The increased investment in water pumping technology was also designed to make the herding work easier and more attractive to contract herders.

\section{Herder opinions of the veterinary cordon fences}

Given the trends towards sedentarisation and management restructuring that occurred amongst the region's pastoralists in the years leading up to, and directly following enclosure in 1996, it comes as no surprise that on the whole, few pastoralists were opposed to the fences. A survey of 53 households from both the village and surrounding cattleposts posed questions regarding the veterinary work conducted by the DAHP; local understanding of the purpose of the veterinary fences; and local perceptions of the positive or negative impacts of veterinary fence enclosure. For the latter question, the survey group was asked to provide their overall opinion of enclosure (i.e. positive or negative), as well as the main reasons for their stance on the fences.

Based on the data collected from the village of Chukumuchu (as opposed to the surrounding cattleposts), the veterinary work and services provided by the DAHP are well received and perceived as positive to local livelihoods. Ninety-six percent of informants in the village consider the work of the DAHP as providing positive benefits to livelihoods, enjoying the free vaccinations and veterinary disease control (Table 1). Complaints over the frequency of the vaccinations and lack of community members employed by the DAHP concern the $4 \%$ who see the veterinary work as negative, with informants suggesting that vaccinations could be done less often to avoid disruption to local lives.

With regard to the CBPP fences, $83 \%$ of the villagers think that the fences provide positive benefits to livelihoods, when given the option between positive, negative or no change. From the remaining pastoralists, $13 \%$ see the fences as having a negative impact on livelihoods, often stating that the fences reduce livestock grazing, prevent the movement of meat, and cut off shortcuts to regional villages and cattleposts. When the $83 \%$ of informants who see the fences as positive were questioned about their reasoning, $54 \%$ replied that the fences stop disease spreading from the north and $42 \%$ stated that the fences stop cattle from straying and reduce stock theft ( $4 \%$ saw no positive impact).

It would, therefore, appear that the fences are generally well received in the region and only cause a minor inconvenience to local livelihoods. However, the survey data

Table 1 Contrasting opinions of DAHP work and CBPP fences from village and cattlepost-based households

\begin{tabular}{lllll}
\hline Region of survey & Opinion of DAHP work + CBPP fences & Positive (\%) & Negative (\%) & Neutral \\
\hline Chukumuchu $(n=24)$ & DAHP & 96 & 4 & 0 \\
Cattleposts $(n=29)$ & DAHP & 79 & 14 & 7 \\
Chukumuchu $(n=24)$ & CBPP fences & 83 & 13 & 4 \\
Cattleposts $(n=29)$ & CBPP fences & 21 & 59 & 20 \\
\hline
\end{tabular}

Source: survey of 53 households in the Chukumuchu region 
from herders at cattleposts in the region surrounding Chukumuchu reveal highly contrasting results. Whilst there are similar opinions regarding the work of the DAHP (79\% see the veterinary work as beneficial), there is a mixture of opinion regarding the impact of veterinary fences as $59 \%$ of informants regard the fences as negative. Furthermore, whilst $21 \%$ of informants from the cattleposts see the fences as positive, $20 \%$ see no positive or negative impacts. Those who see the fences as negative cite blocked short cuts (7\%), restrictions on the movement of meat (7\%), and reduced livestock mobility (38\%) as reasons. The remaining complaints are largely against the lack of maintenance following wet season elephant damage (7\%), rather than conflicts over resources and movement.

The results of this survey illustrate that there is a clear divide between the views of those living within Chukumuchu and those residing at cattleposts within the surrounding rangelands. Given that maintaining access to cattlepost resources is of greatest interest to middle and better-off herders, and that these pastoralists were often looking after the interests of their village-based family, this contrast was significant and represented the views of those most likely to be experiencing the opportunities and constraints of enclosure. Further analysis of views revealed that concerns can be divided between the $14 \%$ of cattlepost dwellers who complain about what, initially, appeared to be minor difficulties caused by enclosure and those who cite longer-term issues such as reduced mobility.

Most people in the region have ties to land or resources found to the north or south of the CBPP fences and enclosure has caused difficulties for people attempting to conduct their usual livelihood activities. Take, for example, the case of DS. DS is 65-yearold Mbukushu woman from Chukumuchu and her husband manages their family herd at the Morambachiwa cattlepost $9 \mathrm{~km}$ to the south of the village. DS also owns cattle at another well in the Xaudum valley to the north of the Samochima fence. DS complains that the fence has made it harder for her to herd cattle between Xaudum and Morambachiwa which she occasionally needs to do, especially after water or grazing become scarce.

'Before the fence I could go alone and just herd the cattle back, now I need a permit and have to employ a herd boy as we have to stop at the fence gate and fill out forms (October 2005)'.

She also complained about the problem of moving meat across the fence, 'if one of my cows die at Xaudum I can no longer bring the meat to my house in Chukumuchu (October 2005)', she continued.

Whilst those who retained access to wells and grazing to the north resent not being able to take meat over the fence or freely move livestock, there are other people who have links to the village of Nxau Nxau to the south of the Ikoga fence. A 58-year-old Herero man from Jobo cattlepost called KK, for example, explained his problems attempting to provide milk and meat for his wife and daughters who live in Nxau Nxau:

'Before the cull I planned to dig a well close to Nxau Nxau so that I could split off some cows and a few goats for my wife and daughters so that they can have some 
milk and meat. The land board granted a permit before the cull but now they have taken the permit away as they don't allow wells within $3 \mathrm{~km}$ of the fence. Now if I want to take a goat to slaughter at Nxau Nxau the vets have to come and inspect the stock and it takes a long time (October 2005)'.

Some people complained about the Ikoga fence blocking direct donkey tracks used to travel between cattleposts and Nxau Nxau village. Most of these complaints were from people at the Xabacha or Nxamazine cattleposts and concerned the added distance required to travel through the Jobo veterinary gate. One old man from Nxamazine explained, 'it's as if my direction is now towards Namibia (October 2005)' due to the need to travel west before heading south to the village. KM a 35-year-old Mbukushu man from the Xabacha II cattlepost explained what happened after the cull when he found that the Ikoga fence now blocked his track:

'Before 1995 we used to go straight to Nxau Nxau on donkey and it would take us from sunrise to about $1 \mathrm{pm}$ to reach the village. After they killed our cattle we went one day on our old track and found the fence blocking our track. We were very angry and it took all day to get to the village. Why didn't they put a small gate for us to use? They must have noticed our track? (October 2005)'

When pressed to provide a negative implication of enclosure most pastoralists could offer one of the above problems. These negative impacts are similar to those documented by Hitchcock $(1995,2002)$, who noted that movement restrictions across the central Ngwato cordon fence during a FMD outbreak prevented the seasonal movement of cattle to village arable lands causing a shortage of milk and draught power. Hitchcock (1995) also described how officials prevented people taking meat and crafts to markets found to the east of the fence by restricting the movement of some goods of animal origin (ibid, p. 184).

During interviews with individual herders whose overall view of the fences is positive or negative, some longer-term concerns emerged, however. Furthermore, pastoralists in the region could be divided into three distinct groups based on their positive or negative position on the fences. The majority of herders concerned about reduced mobility, for example, were either Herero herd patriarchs $>50$ years or young herding households with male household heads $<40$ years. Conversely, of the $21 \%$ who claimed that the fences were positive, the majority welcomed the added enclosure on the grounds that the fences reduced stock loss through cattle straying, and these pastoralists were mainly recently established Hambukushu or Bayei herders. In the discussion below, the views of three households representing a composite of each of these groups are presented.

\section{Welcoming enclosure: recently established Mbukushu herders}

Most pastoralists who viewed CBPP fence enclosure as positive were recently settled Mbukushu herders typically aged between 40 and 50 years old. In many cases, these were households that had used the Herero repatriation as an opportunity to gain access to water and grazing. The case of $\mathrm{KB}$, the Hambukushu owner of Tjiperonga cattlepost, was representative of this group. KB purchased the well from a repatriating Herero herder in the early 1990s and spends most of his time at the cattlepost with his 
eldest son whilst his wife and extended family live at a second homestead in Chukumuchu. Like many pastoralists in the region, KB owns a petrol generator and electric water pump, along with a plastic water tank. Whenever he or his son are alone at the cattlepost they use the generator and pump to provide water for the livestock, as the bucket and winch system requires at least two people to operate productively.

Labour shortages at the cattlepost concerned these herders and is the primary factor leading to their positive position on the fences as $\mathrm{KB}$ explained:

'As you can see I cannot afford to pay a herd boy and rely on my eldest son to help me at the cattlepost while my other children attend school in the village. The fence is good and it stops our cattle straying very far, I can now easily find them as I know they can only go as far as the fence (October 2005)'.

In the dry Kalahari, livestock are physiologically constrained to graze within several kilometres of drinking water, especially in the dry season (Moleele and Perkins 1998). Under the traditional cattlepost system, the borehole or well has been described as effectively 'the herder' due to the reduced need for herding during the dry season (Jerve 1982). Like much of the Kalahari, in the Chukumuchu region there are many ephemeral waterholes or pans often situated along interdune or fossil river valleys. As a result livestock often walk considerably large distances in search of fresh pasture in the wet season as they access these seasonal water sources. Perkins (1996) notes that straying, especially after the first rains, results in much time and effort spent by herders retrieving cattle from distances of up to $40 \mathrm{~km}$ away. Many pastoralists are, therefore, aware that the new CBPP fences and veterinary zones now present a barrier to livestock who can now only stray as far as the Samochima fence to the north, the Ikoga fence to the south, or the Namibian border fence to the east.

Thus, the CBPP fences have benefited herders with limited human capital and this is reflected in the $21 \%$ of herders from the cattleposts and $83 \%$ of herders from the village who recognise the positive outcomes of enclosure. ${ }^{f}$ Veterinary cordon fences and their associated maintenance roads, sporadic gate camps, along with regular maintenance patrols and permanent gate keepers also represent infrastructure and personnel that can be utilised by pastoralists. When cattle fail to return home after release in the wet season, pastoralists begin looking for livestock often relying on the knowledge of other herders who may have seen their cattle in the rangeland. Cattle often stray as far as the veterinary fences where they can be easily seen or tracked. Pastoralists use fence roads to search for livestock, often stopping to ask DAHP gatekeepers if their cattle have been seen along the fence. DAHP officials may also visit cattleposts to inform herders about the location of lost herds.

Beyond reducing stock losses through straying, some pastoralists report that enclosure by the cordon fences has improved livestock security in the region. MS a male Hambukushu herder in a similar situation to KB explained why he welcomes enclosure:

'The fences are good, especially the Samochima fence to the north. Before the fences were made there used to be a lot of cattle stolen to the north and now it 
has decreased. In the past people would steal your cattle during the night and take them to Namibia.(October 2006)'

In Namibia, large tracts of communal rangeland have been compartmentalised and fenced illegally by individuals and small groups of farmers (cf. Werner 2000,Stahl 2000, Stahl 2000) found that reduced stock theft was one of main benefits of illegal fencing and indeed the main determinant driving the impetus to fence. Before the CBPP fences and additional electrified international border fence were constructed in 1995/1996, there was a period after Namibian independence in 1990 when military border security was relaxed and cattle thefts increased in the Xaudum area, probably precipitating the CBPP outbreak itself. It seems for many the cordon fences provide a welcome barrier preventing cattle from straying into remote border regions where the risk of theft remains high.

\section{Increasing vulnerability: Herero herd patriarchs}

Whilst many recently settled Hambukushu and Bayei herders may welcome enclosure, a small group of Herero herd patriarchs remain openly negative towards the cordon fences. This group cites reduced livestock mobility as their primary concern. The views of KB a 60-year-old Herero herd patriarch who manages the household herd at the Boudum cattlepost are representative of those expressed by this group. KB and his family were one of the first herders to pioneer livestock production in the region and he remembers moving to the Xaudum valley to dig a new well with his father in the late 1950s after losing cattle to trypanosomiasis and predators at Nxamasere. In 1984, the family decided to move their permanent onganda to their wet season waterhole, Boudum, as grazing had been depleted at Xaudum due to the ongoing drought. The family kept their cattle permanently at Boudum until 1995 when poor rains and lack of grazing forced KB to move the herd to his brother's well at Xaudum where they remained until the cull.

Since their cattle were restocked in the Chukumuchu region, like many households, they have remained in the area since 1997/1998 and established a village-based homestead. When asked his views about the CBPP fences KB replied, 'it seems as if I'm in a ranch, I can't breath, I can't move anymore'. During discussions with KB and others like him, it was clear that this group were more concerned about the lack of mobility in times of emergency rather than the enclosure of seasonal resources. KB explained why he resented the CBPP fences,

'Before the fences were made you could take your cattle anywhere you wanted. If there was good rainfall at Xaudum you would go there. Before if my well dried up or there was a drought I would be able to go to Nxau Nxau or Xaudum and ask a friend or relative to keep them there. Now, since the fences were made if my well dries up I will have to stay here and my cattle will die here (November 2005)'.

KB's response to enclosure highlights some of the contemporary risks and vulnerabilities facing sedentary pastoralists in the region. The strategy he used to cope with risk in the 1995 drought also illustrates the contemporary context of mobility used before enclosure to mitigate these problems. According to KB, during droughts, his well often runs dry and he is forced to try and dig deeper. Before enclosure by the cordon fence, 
he could draw upon social ties to access water sources elsewhere in the region. Today, with movement restrictions and the permit system, livestock cannot be easily moved across the fences. ${ }^{\mathrm{g}}$

These mobility issues are similar to those faced by sedentary pastoralists enclosed within TGLP ranch areas. Perkins (1996) notes that breakdowns are a frequent occurrence with mechanised boreholes in the Kalahari. Borehole owners often have a network of boreholes and/or contacts and use herd movements, often over large distances, to alleviate breakdowns, droughts and spatial variations in grazing (ibid: 505). Although many herders in the Chukumuchu area owned water pumping and storage equipment, most wells in the region were hand dug and thus equipment failure was just one aspect of the risk faced by pastoralists. Lee (1984) noted that Herero occupation of wells in the Dobe area caused the water table to be lowered dramatically. High utilisation, particularly in the dry season when the water table is at its lowest, can cause wells to dry out and the only solution is to try and dig deeper or move to alternative water sources. The life span and cost of a well depends heavily on whether it is dug through hard calcrete or soft sand. Another serious risk is that wells dug in areas with sandy substrata are prone to collapse (Figure 3)

Since receiving their new livestock, many pastoralists with large herds have adapted to the increased risk through dual well ownership and herd splitting. A number of these households acquired second wells when several became vacant during the Herero repatriation. Most of those who remain reliant on one well spoke of plans or pending applications for a second well permit from the Land Board. These strategies appear a direct adaptation to the increased risks involved as a result of enclosure.

One household fortunate enough to secure a second well was SM's family. Two brothers, MM and SM, cooperatively manage their large herd of cattle between two wells Marunga and Ndivitama. The family's main homestead (onganda) was originally located at Xaudum from where they would occasionally make a seasonal cattle camp at the Marunga waterhole. During the 1980s, the family dug a permanent well at Marunga after the water table dropped at Xaudum and the area became overgrazed. They continued to move seasonally between the two wells until the cull. After being restocked at Chukumuchu, however, they were told by DAHP officials to remain within the veterinary zone.

According to MM, the well at Marunga is one of the deepest in the area and requires a Lister engine to operate. These are more expensive to purchase and maintain. To mitigate the risk of Marunga's well failing the family purchased the Ndivitama well from its Herero owners when they repatriated in 1994. MM explained how the brothers cooperatively manage their herd between the two wells:

'We split our herd between Ndivitama and Marunga because of water. We keep more cows at Marunga as there is more water in that well and it doesn't dry out easily like Ndivitama. There are many waterholes near Marunga also. In the wet season we even take cattle from Ndivitama to Marunga. We then herd them towards the waterholes and fetch them again in the evening.'(October 2005)

The way SM's family adapted their herd management system illustrates both the gradual process of sedentarisation that has occurred in the region and the role played by 


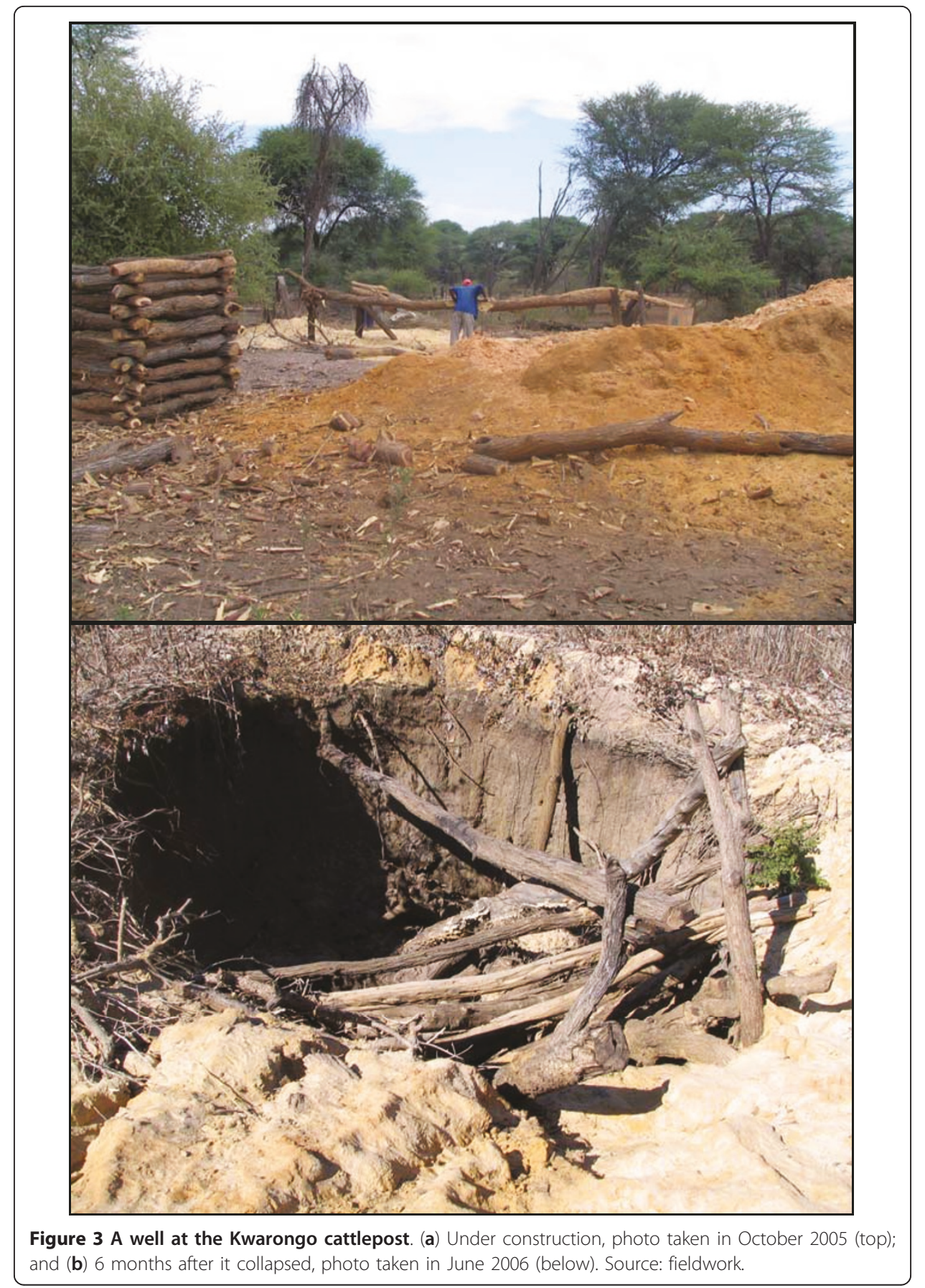

veterinary cordon fence enclosure. It also shows that mobility and flexibility remain important strategies through which pastoralists manage enclosure and sedentarisation. Whereas, in the past the family managed their livestock between the grasslands of the Xaudum valley and Marunga, they now maintain mobility between Marunga and Ndivitama. Dual well ownership and herd splitting represent important strategies by which pastoralists manage the risks and vulnerability of enclosure.

Another major risk facing people in the region is fire. Enclosure by veterinary cordon fences in the region has increased the vulnerability of pastoralists to grazing shortages 
following periodic fire events. WK a 32-year-old Herero man from Kawaronga cattlepost explained why he resented the CBPP fences:

'Look at the land now, it's all burnt up. Before the CBPP cull I could have gone in search of grass for my cattle where the fire hasn't burnt and look for water and then returned when the rains arrived and my area was green. We don't need this fence, before we could trek cattle easily to Shakawe to the community butchers, now we need permits. The fence even kills wild animals (November 2005)'

Historically, pastoralists use fire as a management tool to encourage the growth of grasses and control woody plants and pests (McGahey et al. 2007). In the Kalahari, hunter-gatherer groups have traditionally burnt the savanah to remove dead vegetation and to facilitate hunting and gathering (Perkins et al. 2002). The savannah fire problem even concerned pastoralists who were in favour of enclosure due to the improved security situation. After explaining his overall positive position on fencing MS, a Mbukushu man from Chukumuchu admitted there are problems,

'When the fire burns and then there are poor rains, there is little grazing left for cattle between the fences, but there may be grazing to the north or south in these circumstances (July 2006)'

The issue is compounded by a dramatic increase in the spatial distribution and temporal frequency of burn mosaics throughout the Kalahari since the droughts of the 1980s (Perkins et al. 2002). Most people have noticed a similar trend in the Chukumuchu area. MK, a 52-year-old Mbukushu man explained:

'These days fires are a problem, they burn all over our area. During the $1980 \mathrm{~s}$ you couldn't see fires that often, they would burn only here or there. Even in the early 1990 s when Chukumuchu School was built fires were not this bad. It's only since the cull that fires have become this bad. The problem is this conservation of the environment idea (October 2005)'.

According to Perkins et al. (2002) there are two possible reasons why fires in the Kalahari have become more severe and widespread. First, the almost unprecedented decline in large wild herbivore numbers has increased the volume of dead biomass. Almost every person interviewed from the area stated that there has been a decline in wild herbivores, particularly since the CBPP fences were constructed. This is unsurprising given that veterinary cordon fences represent impermeable barriers for most species and are associated with large-scale declines in water-dependent species in the Kalahari (Thouless 1998,Wheelwright et al. 1996).

The second reason is what MK refers to as the 'conservation of the environment' idea. This concerns the widespread ban on traditional burning practices in the Kalahari which, coupled with the sedentarisation and shift from hunter gathering to livestockdominated modes of production, has caused a reduction in the diversity of spatial and temporal burn mosaics. This, in turn, has increased the frequency of intense and widespread fires (Perkins et al. 2002). The incidence of fires originating from close to fences 
is also reported to have risen following increased human activity along fence roads (Scott Wilson 2000). Finally, whilst veterinary fences can also act as fire breaks, they often trap wildlife attempting to escape bush fires (ibid: 10), with resultant population declines exacerbating the fuel load problem.

It is likely that the reduced stocking rates following the CBPP cull and Herero repatriation have caused a further increase in the volume of dead plant biomass and fire intensity. This was confirmed by local observations of recent environmental changes in the region. According to local people there was an increase of unpalatable shrubs around the cattleposts before the cull. After the livestock were culled, however, the encroachment became even worse as cattle trampling had kept these areas relatively contained.

Whilst shrub encroachment may have increased close to kraals and wells, these areas are found in valley floors where savannah fires often burn out due to the lack of grass. On the dune top savannah, however, intense savannah fires have caused a reduction in mature trees and shrubs. According to natural resource gatherers, savannah fires now regularly destroy crops of wild berries and thatching grass, whilst the reduction in mature trees has reduced the bee population making honey hunting more difficult.

\section{Restricting resource access: young pastoral households under 40 yrs old}

The final group of herders who hold negative positions on the cordon fences were predominantly young pastoral households. Although many young people still plan to farm for cultural reasons, these days most young people prioritise formal and informal employment opportunities as their preferred livelihood activity. During a meeting with a group of young teenagers in Chukumuchu, they discussed the pros and cons of farming and the role it may play in their future livelihoods:

SJ (male 27 years): It's difficult to keep cattle these days. Fires burn all the grass and you may need to buy feed for the cattle. Raising buckets all day to water your cows is hard work so you have to buy a water tank and generator. These things are expensive but its easy to solve these problems if you have a job you can buy fuel and pumps. Without these things you are in trouble. I want to continue making bricks and working as a builder. Maybe one day I will farm, its Tswana culture (October 2005).

KG (female 19 years): I don't want to keep fields, its hard work ploughing and harvesting. Then you have to pound the crop and fix the fences. I want to go to technical college and learn textiles (October 2005).

Whilst there may be an abundance of young people seeking formal and informal cash income opportunities in villages and towns, there were several young households, mainly in their thirties, attempting to establish themselves as independent pastoralists. For the Herero it is traditional for sons, especially the youngest, to 'break with their father' upon reaching adulthood and seek to establish their own cattlepost (Twyman et al. 2001). In the Chukumuchu region, there were several young Hambukushu households attempting to become autonomous as well, though this may be more out of necessity than tradition. These households were often resource poor, with no villagebased homestead or well permit. The problems faced by this group in their efforts to 
gain access to the resources required to construct a pastoral livelihood are demonstrated by the case of MJ and his family.

MJ is 39 years old and was born at Nxau Nxau a village just south of the Ikoga fence where most of his relatives still live. Before the CBPP cull in 1996, MJ herded his 25 cows together with his father's cattle, but like many the family decided to opt for $100 \%$ cash compensation amid speculation that cattle would not be replaced by the government. Since this time, MJ has been busy building his own herd, primarily by working for the Herero in return for access to water and grazing. Households such as MJ's often lack the financial capital to invest in the expensive and risky process of well construction. As a result they find it hard to secure access to permanent water sources that are reliable, free and close to sufficient grazing resources. These issues were central to the negative fence opinion of this group of pastoralists as MJ explained,

'Before the fence I could have taken my cattle to Nxau Nxau where there are lots of wells that I can use for free, now I cannot go through the fence and have to either pay to use a well or work for the well owner (July 2006)'.

For households such as MJ's, there are few options open to access both adequate water and grazing. The only free water available in the Chukumuchu veterinary zone is a government borehole within the heavily grazed communal rangelands surrounding the village of Chukumuchu (Figure 4). However, in addition to the limited availability of grazing, keeping large herds of livestock close to villages is likely to end in conflict as livestock damage crops and other property. Whilst constructing a deep well that

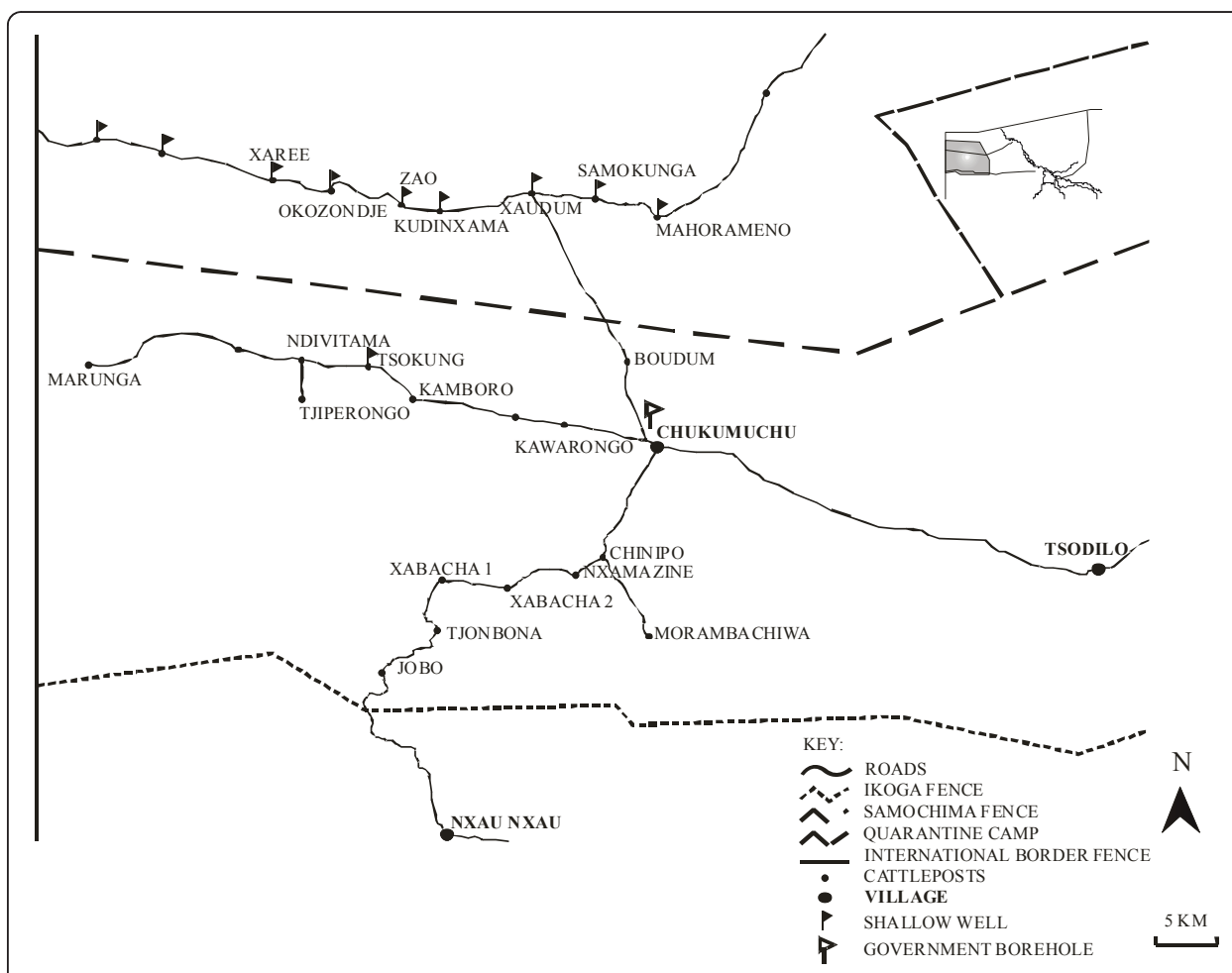

Figure 4 Shallow wells and government boreholes in the Chukumuchu region. (NB: water sources south of Ikoga fence not included in survey). Source: fieldwork 
may be beyond most pastoralists in this group, there are areas where water can be accessed within a short distance from the surface. Most of these, however, are found along the Xaudum valley to the north or near Nxau Nxau village to the south. The only place where shallow wells can be dug in the Chukumuchu region is at Tsokung, a cattlepost already occupied by several households.

There are other key factors besides access to adequate water which such households must consider when attempting to become independent pastoral households. For young herding households such as MJ, who sought access to wells near Nxau Nxau, proximity to villages is also a major concern, as these groups are more reliant on income generated from trading natural resource-based goods to village dwellers,

'I want the Ikoga fence to be removed because there is not enough grazing or water this side for us. If the fence was not there now I would be able to go to Nxau Nxau and find water as there are plenty of waterholes and wells I can use there. Now I have to come up here and beg these Herero to use their well. I would rather be closer to Nxau Nxau as my wife can sell milk and oil in the village and buy maize meal for the family (July 2006)'.

Young families such as MJ's are finding it increasingly difficult to establish themselves as independent herding households. Constrained between the need to access adequate grazing and water on the one hand, and settle within easy distance of settlements in order to participate in local markets on the other, they have been further disadvantaged by the CBPP fences. Such households are often forced to move from one cattlepost to another in search of adequate water and grazing. Livestock are important assets from which the rural poor can construct routes out of poverty, and whilst poorer households may be more reliant on small stock and forage close to settlements, there are examples where some households have managed to accumulate stock and access to extensive rangelands are critical for this to occur (Toulmin et al. 2004, Ellis and Mdoe 2003). It would appear, therefore, that enclosure in the context of the CBPP fences could act to enhance social differentiation within the region's pastoral society.

\section{Conclusion: wider significance for pastoral systems in Africa}

Veterinary cordon fences represent the lynchpin of the southern African disease control system and in Botswana they enable livestock movement control upon otherwise open-access communal rangeland. The continued expansion of veterinary cordon fences into northern regions has facilitated secured access to lucrative export markets for commercial livestock farmers throughout the south of the country. These fences and the area-based disease freedom policies that surround their use represent a striking barrier to pastoral mobility, yet so far few studies have investigated the impact of these structures upon the subsistence pastoral economy.

Tracking changes in herd management, in particular declining livestock mobility, over the period leading up to and including veterinary cordon fence enclosure proved vital to contextualise perceived impacts emerging from the pastoral community. These enquiries revealed that three overall seasonal herd mobility strategies were employed in the past: sedentary herd-release management, wet seasonal mobility in which herders moved to a single water source to avoid conflicts on arable lands, and wet season 
mobility to multiple water sources to track resource availability. Several authors have stressed the importance of socio-economic factors over ecological considerations in determining herding decisions within contemporary pastoral communities (cf. Baker and Hoffman 2006, Turner 1999). Socio-economic changes associated with a gradual shift towards wage-dependency and regional economic development reduced labour availability at the cattleposts, which in turn has led to a reduction in seasonal herd mobility. This empirical evidence demonstrates exactly how household herd management in pastoral societies can become increasingly dominated by non-environmental considerations with increased income diversification.

One might assume that a colonial-era policy instrument that focuses on containment and movement restriction would impact negatively upon a subsistence pastoral society whose primary focus may well be the maintenance of opportunistic and flexible rangeland access (Scoones 1995). Using a detailed examination of the precise societal costs associated with two cordon fences in northern Botswana, this paper illustrates that the situation is less than straightforward. In fact, the majority of herders welcome enclosure, especially those faced with labour shortages after the general movement towards non-agricultural forms of employment. For these groups, veterinary cordon fences reduce the risk of stock theft and provide a useful limit to the movement of lost livestock, especially during the wet season. Furthermore, the increased presence of veterinary personnel either at sporadic gate camps or on regular maintenance patrols represent additional resources that pastoralists can draw upon to locate lost livestock. In Namibia, pastoralists have intentionally created fenced community enclosures, primarily to reduce herding requirements and improve herd security (Werner 2000, Stahl 2000, Twyman et al. 2001). It would appear that faced with declining agricultural labour availability, herders throughout the region are beginning to favour fencing and enclosure over more opportunistic and flexible resource access arrangements.

Whilst the maintenance of flexible resource access may have become of lesser importance to many herders, a small minority of pastoralists outwardly resent the fences (notably elderly herd patriarchs and young herding households). Difficulties experienced gaining access to key resources is creating resentment towards the fences from young pastoral households attempting to 'break with their father' and establish their own household. Constrained between the need to access equitable grazing and water resources on the one hand, and settle within easy distance of settlements in order to participate in local markets on the other, they have been further disadvantaged by the fences. Further work would be needed to determine the wider extent of the problem. This is important, given that studies investigating fencing and enclosure typically emphasise that the removal of flexible systems of resource access disadvantages marginalised groups creating greater social differentiation (Taylor 2006; Peters 1994).

The importance of access qualifications in determining the ability of people to engage their optimal risk management strategies is also emphasised by analysts of societal vulnerability to natural hazards (Wisner et al. 2004). Well failure, savannah fires and drought represent persistent risks or hazards to which livestock production in the region is exposed. Awareness of the increased vulnerability to hazards such as savannah fires and hand-dug well failure that enclosure presents caused some experienced pastoralists to oppose enclosure. In a direct attempt to mitigate their increased vulnerability to natural hazards, these herders have attempted to adapt to enclosure by 
securing dual well ownership, herd splitting and practising seasonal mobility. Further work is needed to investigate how pastoralists enclosed by veterinary fences cope with risks over longer time periods. This temporal approach is especially important given that long-term exposure to hazards can initiate a 'ratchet effect' whereby the ability of households to respond to subsequent shocks may be lessened (Wisner et al. 2004).

In extending marketing opportunities to marginalised pastoral areas, disease management in Botswana is often regarded as a model that could help to catalyse Africa's currently underdeveloped potential for livestock production. Such assertions surround current efforts to re-establish a fenced export zone in eastern Africa, for example (Kock 2010). Focusing on the case of veterinary cordon fencing in northern Botswana, this paper illustrates the exact societal costs and benefits associated with the policy instrument. Whilst on balance fences may have reduced herding demands and improved livestock security, negative implications for resource access and pastoral risk management raise concern.

From a wider policy perspective, questioning these assumptions is timely given the recent animal health policy dilemmas facing the southern African region (cf. Scoones and Wolmer 2006, Scoones et al. 2010). With rapidly changing political, economic and policy contexts, it is argued that the conventional area-based animal health policy is unlikely to remain relevant in its current form in southern Africa, especially with uncertainty over the future of preferential trade agreements and escalating costs associated with sanitary and phyto-sanitary compliance. This is an increasingly complex issue with a range of scientifically acceptable options of disease control and livestock marketing opening up before decision makers (for a review see Scoones et al. 2010). The findings emerging from this study suggest that policy-marketing pathways which require less fencing and offer more flexible resource access such as a commodity-based trade (Thomson et al. 2004), may well be preferable within communal pastoral areas.

\section{Endnotes}

${ }^{a}$ Globally, drylands occupy $41 \%$ of the global land surface and are home to $35 \%$ of the population (Safriel et al. 2005). Of these, an estimated 100 to 200 million are pastoralists and the production system is the most widespread on earth practised on at least two-thirds of global drylands (Davies and Hatfield 2007). Throughout this paper, I use the term pastoral drylands to refer to development issues present in these regions.

${ }^{\mathrm{b}}$ Interview with KM (November 2005)

${ }^{\mathrm{c}}$ Interview with KK (October 2005)

${ }^{d}$ Fifty-four percent (54\%) choose 100\% cash compensation and 23\% choose $70 \%$ cash compensation (Fidzani et al. 1999).

${ }^{\text {e }}$ Source: fieldwork survey $(n=53)$

${ }^{\mathrm{f}}$ Human capital refers to the labour available to the household and changes constantly due to internal demographic reasons (e.g. births, deaths etc.) and to deliberate restructuring to meet unexpected events (e.g. divorce) or external pressure (Ellis 2000).

${ }^{\mathrm{g}}$ Cattle can be moved in a northerly direction across the fences but only after applying for a movement permit. This can take some time as veterinary officials only occupy their village-based office during vaccination campaigns and pastoralists must often travel to Shakawe and visit the district office. Few animals have been moved south over 
the fences as this would require either a veterinarian to visit the cattlepost and inspect stock or livestock to spend 21 days in quarantine which would incur fees.

\section{Acknowledgements}

Research referred to throughout this paper was funded by the Economic and Social Research Council, Natural Environmental Research Council and Hertford College Oxford. My thanks are extended to the people of Chukumuchu for taking the time to participate in the research and to the Department of Animal Health and Production for granting a permit to conduct this study. I also extend my gratitude to David Thomas and Patricia Daley of Oxford University for their valuable support, advice and comments on this research. Similarly, thanks to the referees of this paper for their valuable comments.

\section{Authors' contributions}

DJM was solely responsible for the preparation of material presented in this manuscript including all data collection, analysis and write up.

\section{Competing interests}

The author declares that they have no competing interests.

Received: 7 February 2011 Accepted: 24 June 2011 Published: 24 June 2011

\section{References}

Adriansen, HK, and TT Nielsen. 2002. Going where the grass is greener: On the study of pastoral mobility in Ferlo, Senegal. Human Ecology 30: 215-226.

Almagor, U. 1981. Pastoral identity and reluctance to change: The Mbanderu of Ngamiland. Journal of African Law 24: 35-61.

Baker, LE, and MT Hoffman. 2006. Managing variability: Herding strategies in communal rangelands of semiarid Namaqualand, South Africa. Human Ecology 34: 765-784.

Behnke, RH, I Scoones, and C Kerven. 1993. Range ecology at disequilibrium: New models of natural variability and pastoral adaptation in African savannas. London: ODI 248.

Bensen, H, and T Meyer. 2002. The dynamics of land use systems in Ngamiland: Changing livelihood options and strategies. http://www.okavangochallenge.com. Accessed 15 January 2005.

Boone, RB, and NT Hobbs. 2003. Lines around fragments: The effects of fencing on large herbivores. In Allsopp, N, Palmer, AR, Milton, SJ, Kirkman, KP, Kerley, GIH, Hurt, CR and Brown, CJ. (eds.) Proceedings of the VIlth International Rangelands Congress, Durban, South Africa, 580-591.

Bollig, M, and JB Gewald. 2000. People, cattle and land: Transformations of a pastoral society in southwestern. Africa, Koln: Rudiger Koppe Verlag.

Coppolillo, PB. 2000. The landscape ecology of pastoral herding: Spatial analysis of land use and livestock production in East Africa. Human Ecology 28: 527-560.

Darkoh, MBK, and JE Mbaiwa. 2002. Globalisation and the livestock industry in Botswana. Singapore Journal of Tropical Geography 23(2): 149-166.

Davies, J, and R Hatfield. 2007. The economics of mobile pastoralism: A global summary. Nomadic Peoples 11(1): 91-116.

Desta, S, and DL Coppock. 2004. Pastoralism under pressure: Tracking system change in southern Ethiopia. Human Ecology 32(4): 465-486.

Ellis, F. 2000. Rural livelihoods and diversity in developing countries. Oxford: Oxford University Press.

Ellis, F, and N Mdoe. 2003. Livelihoods and rural poverty reduction in Tanzania. World Development 31: 1367-1384.

Fidzani, B, WS Mlenga, M Athopheng, and MM Shatera. 1999. Socio-economic effects of CBPP in Ngamiland, Division of Agricultural Planning and Statistics, MoA.

Fratkin, E. 1997. Pastoralism: Governance and development issues. Annual Review of Anthropology 26: 235-261.

Fratkin, E, and R Mearns. 2003. Sustainability and pastoral livelihoods: Lessons from east African Maasai and Mongolia. Human Organization 62: 112-122.

Hitchcock, RK. 1995. Centralisation, resource depletion, and coercive conservation amoung the Tyua of the Northern Kalahari. Human Ecology 23(2): 169-196.

Hitchcock, R. 2002. Coping with uncertainty: Adaptive responses to drought and livestock disease in the northern Kalahari. In Sustainable Livelihoods in Kalahari Environments: Contributions to Global Debates, eds. Sporton, D, Thomas, DSG, 161-192. Oxford: Oxford University Press.

Hobbs, JCA. 1981. The environmental impact of veterinary cordon fences. African Wildlife 35(6): 16-21.

Jerve, AM. 1982. Cattle and inequality: A study of rural differentiation from southern Kgalagadi in Botswana. Bergen: DERAP Publications, Chr. Michelson Institute.

Kivaria, FM. 2003. Foot and mouth disease in Tanzania: An overview of its national status. Veterinary Quarterly 25: 72-78.

Kruger, FW. 1998. Identity building and social transformation: The cases of Namibia and Botswana compared. Geojournal 46(2): 79-87.

Kock, R. 2010. The newly proposed Laikipia disease control fence in Kenya. In Fencing impacts: A review of the environmental, social and economic impacts of game and veterinary fencing in Africa with particular reference to the Great Limpopo and Kavango-Zambezi Transfronier Conservation Areas, eds. Ferguson, K, Hanks, J (eds), 71-74. Pretoria: University of Pretoria, Mammal Research Institute.

Lee, R. 1984. The Dobe Ju/'hoansi. Toronto: Holt, Rinehart and Winston, Inc.

Madsen, LM, and HK Adriansen. 2004. Understanding the use of rural space: The need for multi-methods. Journal of Rural Studies 20: 485-497.

Manzano, P, and R Casas. 2010. Past, present and future of Transhumancia in Spain: Nomadism in a developed country. Pastoralism 1(1): 72-90. 
McAllister, RRJ. 2010. Livestock mobility in arid and semi-arid Australia: Escaping variability in space. Pastoralism 1(1): 37-54.

McGahey, D, J Davies, and E Barrow. 2007. Pastoralism as Conservation in the Horn of Africa: Effective policies for conservation outcomes in the drylands of eastern Africa. Annals of the Arid Zone 46: 353-377.

McPeak, JG, and PD Little. 2006. Pastoral Livestock Marketing in Eastern Africa: Research and Policy Challenges. London: Intermediate Technology Publications Ltd, pp. 288.

Moleele, NM, and JS Perkins. 1998. Encroaching woody plant species and boreholes: Is cattle density the main driving factor in the Olifants Drift communal grazing lands, south-eastern Botswana? Journal of Arid Environments 40(3): 245-253.

Moore, DS. 1993. Contesting terrain in Zimbabwe's eastern highlands: Political ecology, ethnography and peasant resource struggles. Economic Geography 69: 380-401.

Mullins, GR, B Fidzani, and M Kolanyane. 2000. At the end of the day-the socioeconomic impacts of eradicating contagious bovine pleuropneumonia from Botswana. Tropical Veterinary Diseases 916: 333-344.

Ndzinge, L, J Marsh, and R Greer. 1984. Herd inventory and slaughter supply response of Botswana beef cattle producers. Journal of Agricultural Economics 35: 97-107.

Niamir-Fuller, M, and MT Turner. 1999. A review of recent literature on pastoralism and transhumance in Africa. In Managing mobility in African rangelands: The legitimization of transhumance, ed. Niamir-Fuller, M., 18-46. London: IT Publications.

Niamir-Fuller, M. (ed) 1999. Managing mobility in African rangelands: The legitimization of transhumance. London: IT Publications.

Pennington, R. 1992. Did food increase fertility? Evaluation of !Kung and Herero History. Human Biology 64: 497.

Pennington, R, and H Harpending. 1991. Infertility in Herero pastoralists of Southern Africa. American Journal of Human Biology 3: 135-153.

Perkins, JS, G Stuart-Hill, and B Kgabung. 2002. The impact of cattle-keeping on the wildlife, vegetation, and veld products. In Sustainable Livelihoods in Kalahari Environments:Contributions to Global Debates, eds. Sporton, D, Thomas, DSG. 67-90. Oxford: Oxford University Press.

Perkins, JS. 1996. Botswana: Fencing out the equity issue. Cattleposts and cattle ranching in the Kalahari Desert. Journal of Arid Environments 33: 503-517.

Perkins, JS, and DSG Thomas. 1993. Spreading deserts or spatially confined environmental impacts? Land degradation and cattle ranching in the Kalahari of Botswana. Land Degradation and Rehabilitation 4: 179-194.

Peters, P. 1994. Dividing the Commons: Politics, Policy, and Culture in Botswana. Charlottesville: University Press of Virginia.

Reid, RS, PK Thornton, and RL Kruska. 2003. Loss and fragmentation of habitat for pastoral people and wildlife in east Africa: Concepts and issues. In Proceedings of the VIlth International Rangelands Congress, Durban, South Africa, eds. Allsopp, N, Palmer, AR, Milton, SJ, Kirkman, KP, Kerley, GIH, Hurt, CR, Brown, CJ 580-591.

Republic of Botswana 2001. 2001 Population and housing census: Population of towns, villages and associated localities. Gaborone: Central Statistics Office, Government Printer 167.

Safriel, U, Z Adeel, D Niemeijer, J Puigdefabregas, R White, R Lal, M Winslow, J Ziedler, S Prince, E Archer, and C King. 2005. Chapter 22: Dryland systems. In Millenium Ecosystem Assessment. Ecosystems and human well-being: Current state and trends. Volume 1, eds. Hassan, R, Scholes, R, Ash, N 623-662. Washington, DC: World Resources Institute.

Scoones, I. 1995. Living with uncertainty: New directions for pastoral development in Africa. London: Intermediate Technology Publications.

Scoones, I, and W Wolmer. 2006. Livestock, disease, trade and markets: Policy choices for the livestock sector in africa. Brighton: IDS Working Paper 269.

Scoones, I, A Bishi, N Mapitse, R Moerane, ML Penrith, R Sibanda, G Thomson, and W Wolmer. 2010. Foot-and-mouth disease and market access: Challenges for the beef industry in southern Africa. Pastoralism 1(2): 135-164.

Scott Wilson Resource Consultants 2000. Environmental impact assessment of the veterinary fences in Ngamiland. Summary report for the Government of Botswana Edinburgh 105.

Smith, AB. 1992. Pastoralism in Africa: Origins and development ecology. London: Hurst and Company.

Stahl, U. 2000. At the end of the day we will fight: Communal land rights and illegal fencing in the Otjozondjupa Region. In People, Cattle and Land: Transformations of a Pastoral Society in Southwestern Africa, eds. Bollig, M, Gewald, J, 319-346. Koln: Rudiger Koppe Verlag.

Sutmoller, P. 2002. The fencing issue relative to the control of foot-and-mouth disease. Annals of the New York Academy of Sciences 969: 191-200.

Taylor, JL. 2006. Negotiating the Grassland: The Policy of Pasture Enclosures and Contested Resource Use in Inner Mongolia. Human Organization 65(4): 374-386.

Theis, J, and H Grady. 1991. Participatory Rapid Appraisal for Community Development: A training manual based on experiences in the Middle East and North Africa. London: IIED.

Thomas, DSG, and PA Shaw. 1991. The Kalahari Environment. Cambridge: Cambridge University Press.

Thomson, G, E Tambi, S Hargreaves, T Leyland, A Catley, G van 't Klooster, and M Penrith. 2004. International trade in livestock and livestock products: The need for a commodity-based approach. Veterinary Record 155: 429-33.

Thouless, C. 1998. Large mammals inside and outside protected areas in the Kalahari. Transactions of the Royal Society of South Africa 53: 245-255.

Toulmin, C, C Hesse, and L Cotula. 2004. Pastoral common sense: Lessons from recent developments in policy, law and practice for the management of grazing lands. Forests, Trees and Livelihoods 14: 243-262.

Turner, MD. 1999. Labor process and the environment: The effects of labor availability and compensation on the quality of herding in the Sahel. Human Ecology 27: 267-296.

Turner, MD, and P Hiernaux. 2002. The use of herders' accounts to map livestock activities across agropastoral landscapes in semi-arid Africa. Landscape Ecology 17: 367-385.

Twyman, C, A Dougill, D Sporton, and D Thomas. 2001. Community fencing in open rangelands: Self-empowerment in Eastern Namibia. Review of African Political Economy 87: 9-26.

UNDP. 2003. Pastoralism and mobility in the drylands. The global drylands imperative, Second Challenge Paper Series. http:// www.energyandenvironment.undp.org/undp/index.cfm?module=Library\&page=Document\&DocumentID $=5572$. Accessed on 5 January 2005.

Vivelo, FR. 1977. The Herero of western Botswana: Aspects of change in a group of Bantu-speaking cattle herders. St. Paul: West Publishing Co, 232 
Werner, W. 2000. From communal pastures to enclosures: The development of land tenure in Herero reserves. In People, Cattle and Land: Transformations of a Pastoral Society in Southwestern Africa, eds. Bollig, M and J Gewald. Koln: Rudiger Koppe Verlag.

Wheelwright, NT, JM Dangerfield, M Flyman, and M Tjibae. 1996. Strengthening biological theory in wildlife research and management: A case study for Botswana. South African Journal of Science 92(4): 173-177.

Wisner, B, P Blaikie, T Cannon, and I Davies. 2004. At risk: Natural hazards, people's vulnerability and disasters, 2nd edn. London: Routledge.

doi:10.1186/2041-7136-1-14

Cite this article as: McGahey: Livestock mobility and animal health policy in southern Africa: the impact of veterinary cordon fences on pastoralists. Pastoralism: Research, Policy and Practice 2011 1:14.

\section{Submit your manuscript to a SpringerOpen ${ }^{\circ}$} journal and benefit from:

- Convenient online submission

- Rigorous peer review

- Immediate publication on acceptance

- Open access: articles freely available online

- High visibility within the field

- Retaining the copyright to your article

Submit your next manuscript at $\boldsymbol{s p r i n g e r o p e n . c o m ~}$ 